\title{
Parents' Role in Assisting Children to Study from Home during the Covid-19 Pandemic
}

\author{
Dwi Novita Sari ${ }^{1}$, Meida Rachmawati ${ }^{2}$ \\ \{keziadwinovitasari@gmail.com ${ }^{1}$, meidarachmawati@gmail.com² ${ }^{2}$, \\ Sekolah Tinggi Teologi Sangkakala ${ }^{1}$, Universitas Ngudi Waluyo Semarang ${ }^{2}$
}

\begin{abstract}
The Pandemic period has changed learning activities at school into learning from home. In this case, the role of teachers in schools has to be carried out by parents at home. Of course, many obstacles arise considering that not all parents can assist children in learning like teachers at school. This review will investigate the job of guardians in going with kids while considering from home during the COVID-19 pandemic. The strategy used to concentrate on this paper is scientific distinct. The article expects to discover which jobs that completed by guardians while going with their youngsters during the Covid-19 pandemic. The results showed that parents act as mentors, educators, facilitators, and motivators. In helping the children's activity, parents needed guidance to assist children's exercise based on their needs while learning from home.
\end{abstract}

Keywords: The Role of Parents; Learning from Home; The Covid-19 Pandemic

\section{Introduction}

The Covid-19 virus that has hit various worldwide countries has become a pandemic outbreak that has brought many changes. Diverse lines are its economy, government, industry, and even education require more than just adaptation. It is necessary to develop new habits and strategies to restore the existing economy and educational processes. Government policies were issued to tackle this epidemic. Concerning training, the methodology gave incorporate Government Regulation Number 21 of 2020 concerning Large-Scale Social Restrictions, in the Context of Accelerating the Handling of Covid-19 that outcomes in limitations on different exercises incorporate schools. In the mean time, Learning from Home (BDR) practices were authoritatively given through the Circular Letter of the Minister of Education and Culture Number 36962/MPK.A/HK/2020 in regards to internet taking in and telecommuting to forestall the spread of Corona Virus Disease (COVID-19). This arrangement requires educators and understudies to proceed to work and study from home from PAUD to Higher Education levels [1]. This approach positively doesn't just affect the connection among instructors and understudies while Study from Home (SFH), yet additionally the significance of upgrading the job of guardians in the execution of SFH.

The role of parents in accompanying children during learning at home determines the child's success in understanding studying. Therefore, the function of parents is very central. According to Nurlaeni, learning assistance for children, especially for children under ten years of age, has a very urgent role and needs to be influenced by positive and constructive 
parenting patterns were built in the family. The improvement of the guardians' job who at first assumed a part in directing fundamental perspectives and abilities, like strict training to submit to the guidelines, and for positive routines [2]. As of now, it has become far and wide, in particular as an ally for scholarly training. The obligation of guardians is likewise underscored by Prabhawani expressing that the execution of instruction is the obligation of guardians and the encompassing local area, not just the obligation of instructive foundations [3].

The role of parents in the family includes many things, including financing (sustenance), inculcation of moral values, customs, and protection against violence in the family. If these roles have not been fulfilled, the family will experience dysfunction. No wonder many children behave poorly or even have an unconfident attitude. Lestari expressed that the family is seen from its capacity, specifically having the obligation and capacity of care, passionate and material help, and the satisfaction of explicit jobs [4]. The family is a basic piece of the neighborhood that finishes the truly zeroing in limit on teaching, guaranteeing, and supporting children. Thusly, the individual, character, attitude, level of improvement, and moral and social potential gains of young people are affected by family adolescence. As per this, Rakhmawati, communicated that child care is a nonstop development through the collaboration pattern of watchmen and children to stimulate ideal turn of events and progression of young people [5]. It shows that as of recently, the occupation of gatekeepers in supporting and care is more recognizable, while educational preparing is imparted to schools.

This phenomenon occurred before the COVID-19 pandemic took place. After the Covid19 pandemic, the BDR policy made the role of parents more complex, namely as school (academic) teachers at home. The parents' role determines a child's academic success. This study is vital considering the emergence of difficulties in assisting children's learning during a pandemic, both challenges experienced by parents and learning difficulties experienced by children. It needs to be studied and handled so that the role of mentoring learning from home can run well and children can achieve the academic abilities determined by the school. This study explores the roles that appear in the guidance efforts carried out by parents to children during the learning process from home.

\section{Methodology}

The technique utilized in this review is the writing survey strategy. The writing survey strategy is the hypothesis, discoveries portrayal, and other exploration materials got from reference materials to be utilized as a beginning stage for research exercises and foster a reasonable temper from the definition of the issue to be examined. The writing survey contains a rundown audit and the writer's contemplations on a few library sources (articles, books, slides, data, and so forth) identified with the examination points talked about. The Literature Review method was used in this research study to provide a clear picture to the readers of the parents' role who appear in accompanying children during Learning from Home activities. The research procedure is, firstly, researchers collect various works of literature as the basis for research. Secondly, researchers examine and analyze. Finally, the researcher concludes the results of the studies and analyzes that have been carried out. 


\section{Results and Discussion}

The other side of the Covid-19 phenomenon seems to be returning the family's position as the center of activity, whether it's education, work, and worship from home. The family as the principal establishment that teaches and outfits every person with moral, social, strict, and social qualities is an underlying capacity that is as of now being expanded with the undertaking of instructing scholastically through learning help gave to their kids. The family can't be isolated from the kid's life, which is the central and first spot in quite a while life. The family assumes a significant part in ingraining propensities and examples of conduct, just as imparting esteems, religion, and ethics as per age and culture in the family [6]. The Government Regulation of the Republic of Indonesia Number 21 of 1994 concerning the Implementation of Prosperous Family Development has expressed that the family has the elements of adoration and friendship, assurance, schooling, values, religion, ethics, and social. Alfiana articulated that the family is the essential spot or the beginning spot and the nearest place for kids on the grounds that there is a lot of spare energy to go through with kids in the family [7]. It was found that there are at least four fundamental roles for parents in assisting children to learn from home during the COVID-19 pandemic.

\subsection{Parents as Educators}

Giving instruction or schooling is a capacity and job of the family. Based on PP No. 87 of 2014, there are family functions, one of which is the function of socialization and education, namely the role of the family in providing care, caring for, and educating offspring based on their stage of development, which aims to produce quality offspring in the environment and future life [8]. Family is the primary discussion to give training to relatives [9]. The duties of parents as educators have been carried out long before the pandemic. Parents teach many things to children in living life, learning independently, and teaching religious, moral, social, and cultural values. Scholarly instruction is appointed to educators who are regularly arranged to the conveyance of explicit topic. Notwithstanding, this pandemic circumstance urges guardians to assume an all the more part. The worth of instruction given by guardians isn't simply situated to teaching positive practices that can uphold the accomplishment of youngsters' government assistance yet additionally participating in instructive help scholastically.

Regarding the role of parents in accompanying children to study at home, Pramudyani stated that parents have a function to educate children and become teachers at home for their children, especially mothers [10]. In view of a review led by Arsendy et al. expressed that there is a gathering of moms who invest 2-3 hours more energy each day than fathers who burn-through under an hour going with their kids when learning at home [11]. For this situation, it can say that guardians play a functioning part in helping kids to learn at home despite the fact that the mother's obligation is more in investing energy. In accordance with this, Gloria, in her assessment expressed that the Covid-19 pandemic has its insight for guardians since guardians can screen their kids straightforwardly and give direct direction in their youngsters' learning cycle so kids will be nearer to their kids. guardians and guardians can discover the challenges looked by their youngsters [12]. The job of guardians is to assist kids in managing these learning hardships. 


\subsection{Parents as Mentors}

Parents play a role in guiding their children can lead to been set goals. For example, for children of certain ages, parents have purposes that their children need to achieve so that later they become adults and have good character. For example, a 7-years old child should be able to eat by himself without being fed and bathe himself. The role of parents in guiding is to direct their children by creating activities that encourage children to practice. If there is a mistake, then the parent instructs to do the right thing. There are two kinds of mentoring, namely personality coaching and academic guidance.

Personality guidance is all efforts made by parents to direct their children to have a good personality. By teaching moral, social, spiritual values through daily parenting patterns and the example given. While academic guidance is guidance given when children learn school assignments. This guidance is in the form of directing children to the aims and objectives of learning. Sometimes parents explain what the teacher says to the child. Parents remind each task and ask the child to be able to do it. That is why, at this time of the pandemic, it is not only difficult for teachers to deliver teaching. But moreover, this difficulty is experienced by parents as partners in teaching children. Therefore, the success of learning from home during this pandemic determines by the guidance of the parents.

The difficulties experienced by parents in the mentoring process as learning guides for children are the educational background of parents who are less qualified, the lack of parental teaching skills that they cannot understand how to guide children in learning. During the pandemic, parents also need to lead their children to be able to comply with the health protocols that apply in the school environment and at home. The guiding role is carried out by reminding their children to wash their hands with soap and running water, use a mask when leaving the house, maintain distance, reduce mobility and stay away from crowds. Guardians need to remind their youngsters to apply a solid and clean way of life to keep away from different infections.

According to Graha, the parents' treatment always guides understanding and training to children about cleanliness and tidiness to be able to make children maintain personal hygiene. [13]. Not only reminding them to maintain a healthy lifestyle, but the role of parents is also to maintain and ensure that children stay healthy and ensure that children adopt a healthy lifestyle correctly. Parents need to give love to their children besides in the form of education and trust, but it is also vital to constantly control the development of their children. Children can learn faster by imitating, so it is important to give examples and habituation given by the teacher, especially parents. It is also in line with Ihsani \& Santoso's opinion that the role of parents at home is crucial in providing education to children to maintain a clean environment. This education is conveyed to children by setting an example to always wash their hands after outdoor activities, is assessed as imminent to raise awareness about environmental hygiene [14]. In addition, the role of parents also ensures that children consume nutritious food, sleep regularly, wash their hands regularly, and actively play.

Training children to always live clean and healthy in line with one of the activities in the positive parenting program (Triple $\mathrm{P}$ ) that aims at developing individual capacity for selfregulation [15]. Self-guideline is the interaction by which people are trained abilities to change their conduct and become answers for issues in the more extensive social climate identified with nurturing and family. Positive parenting can be used as a family parenting model so that it becomes a solution in maintaining and ensuring children live a clean and healthy life with self-regulation. According to Mattewakkang, in the learning process at home (SFH), it is hoped that teachers and parents can realize education that does not only focus on academic or 
cognitive achievement, but can realize meaningful education, mutual understanding is needed from the government, schools, and the community and the three elements. must work together [16]. It is in accordance with what is expressed in the objectives of public schooling controlled in the Law of the Republic of Indonesia Number 20 of 2003 article 3, to be specific "public training expects to foster the capability of understudies to become individuals who accept and dread God Almighty, have an honorable person, sound, proficient, competent, inventive, autonomous, and become a popularity based and dependable resident".

\subsection{Parents as Facilitators}

Including all parts of instruction to guarantee the execution of the learning system in an alternate environment, in particular at home, planning educational plan and getting the hang of following the states of the Coronavirus pandemic, giving persuasive support and appreciation to educators, understudies, and guardians, leading web based preparing on distance learning (PJJ), sending writes about kids' every day assignments to the training office by means of internet, conveying in one bearing as well as in multi manner to disinfect schooling units is something outright to do in this pandemic condition [17]. It illustrates the role of parents in facilitating children in learning from home during the pandemic. The position of parents is the teacher's partner in educating but also a facilitator in educating. The job can happen well when given rules that observe the necessities of the present kids. For instance, the aide shows perfect and solid living conduct, critical thinking abilities, decisive reasoning, cooperation and correspondence, media and innovation data proficiency, inventiveness and advancement just as ICT that are abilities required in the 21st century towards kids during BDR will assist with accomplishing ideal improvement of their children and little girls.

Generation 4.0 is far comfortable by the existence of rapid technology. Students can access a variety of knowledge to complement their learning understanding, and it is not uncommon for them to learn independently. The teacher's role in providing knowledge and learning can substitute because of these conveniences, but technology cannot provide a filter for information other than his child who makes this possible. In this case, the role of the teacher is irreplaceable. The teacher becomes a facilitator for the students. The teacher facilitates when students ask questions to get access to answers from what the child wants to know and also becomes a filter for information that is not good for children. Thus, the role of the facilitator is currently performed by parents at home during the BDR and Limited Face-to-face Learning (LFFL).

As facilitators, parents need to provide quality time to build togetherness among family members. Harmaini stated that parental togetherness is necessary because they understand the level of child development and the things needed, togetherness with children starts from the time the child is not born until they are teenagers, according to the needs of each child [18]. The busyness of everyday life often results in limited time with children. Thus, closeness will be built, and children are more comfortable when asking questions because they experience particular difficulties in the learning process. Comfortable family conditions support children to study quietly and not feel burdened with the tasks at hand. Parents need to upgrade themselves can facilitate all children's curiosity coursed through questions to parents. The facilitator also talked about how parents provide tools, materials, and other learning needs of children that can support the BDR learning process to be comfortable. 


\subsection{Parents as Motivators}

Motivation is needed in the learning process. It is because, in the learning progression, it is not uncommon to find difficulties in learning. It sometimes makes students tired, bored, and even desperate and has no enthusiasm to learn. If this is allowed, then the learning outcomes will be worse. Students are threatened with not going to class or graduating. Education standards are declining. It certainly has a negative impact not only on the children's future but also on the school. During a pandemic that requires BDR, the element of boredom will appear. Children who are usually free to explore learning activities anywhere are limited because of the proper Health Protocol. Therefore, the role of parents as motivators for children's learning during BDR is crucial and needed.

As an inspiration, guardians need to fabricate correspondence with kids in the family. As indicated by Murtiningsih, building up correspondence among guardians and youngsters is crucial on the grounds that it will reinforce the connection among guardians and kids. Through correspondence, guardians will know the youngster's desires, and guardians can pass on what they need or expectations and backing for their kids [19]. That way, children will be more open to their parents, and vice versa, the parents will be more open to their children can create a warm and comfortable family atmosphere. With this condition, when children have learning difficulties, they do not hesitate to convey it to their parents. Likewise, parents will comfortably provide input that motivates children to continue to want to the learning process.

Positive correspondence will fabricate positive nurturing in the family showed by listening mindfully and zeroing in on the discussion. As per the Ministry of Education and Culture, the job of guardians when at home is to make propensities, make a protected, agreeable and charming climate, and sustain emphatically. Giving a feeling that everything is good and solace to kids should be possible by guardians by building connections with kids, for example, in giving friendship through embraces, slings, embraces, embraces, and strokes from guardians [20]. A lovely learning environment while at home, cultivating character, and accomplishment. Accomplish for the development and advancement of youngsters and to

fortify the connection among guardians and kids to urge kids to be sure and to establish a climate that isn't just safe for kids. Yet additionally, agreeable and fun and should be possible by doing exercises together, like playing, doing schoolwork as indicated by their capacities, visiting, and doing things the youngster likes.

Nurkholis, in his exploration, expressed that the effect of the Covid-19 pandemic circumstance on understudies was fatigue and weariness. For this situation, the job of guardians is to direct and inspire kids so youngsters stay excited in doing exercises at home [21]. Youngsters have the inspiration to accomplish something in case they get support from individuals nearest to them, like guardians. As per Sardiman, inspiration is a progression of endeavors in making specific conditions to give incitement so somebody needs to accomplish something [22]. Guardians need to peruse the circumstance experienced by the kid and show responsiveness to the condition. Responsiveness is incorporated love, backing, and warmth. In directing and inspiring youngsters, guardians need to zero in on correspondence among guardians and kids. Communication can be effective if parents and children have close relationships, like, understand, and are open to each other. In addition, guiding and providing motivation requires emotional awareness as the basis of parenting because powerful emotions have a strong influence in triggering automatic thought processes, including behaviors that tend to be destructive. 


\section{Conclusion}

The COVID-19 pandemic has forced parents to adapt by developing their role in assisting children to learn from home. The results showed that generally, the parents' roles that emerged during the COVID-19 pandemic were as educators, mentors, facilitators, and motivators. Specifically, it showed that the function of parents as educators is experiencing development, namely those who initially teach moral, spiritual, social, and cultural values to become educators in academic learning. The role of parents as mentors has developed from initially only guiding in terms of children's behavior to being mentors for children's school assignments and advising them to obey the Health protocol. The role of parents as facilitators in online learning is crucial considering that online learning demands a vital role for parents in facilitating children's learning, namely through online learning facilities from home and facilities in obtaining answers to the information needed by children during learning. Meanwhile, the role of parents in learning assistance, namely as a motivator, is no less important during this pandemic. Parents are a milestone where children can be enthusiastic about learning and go through learning difficulties without giving up. Parents need to overcome the boredom that often arises in the learning process from home by motivating children. By good coordination and communication between the school and parents, it will help the SFH process to be well connected. In general, teachers are no longer partners of parents, but now parents are partners of teachers in carrying out their duties as academic teachers at home.

\section{References}

[1] Nadim A. Makarim. (2020). Surat Edaran No. 4 Tahun 2020 (p. 1). https://www.kemdikbud.go.id/main/blog/2020/03/mendikbud-terbitkan-se-tentangpelaksanaan-pendidikan-dalam-masa-darurat-covid19.

[2] Nurlaeni, N., \& Juniarti, Y. (2017). Peran Orang Tua Dalam Mengembangkan Kemampuan Bahasa Pada Anak Usia 4-6 Tahun [The Role of Parents in Developing Language Skills in Children aged 4-6 Years]. Jurnal Pelita PAUD.

[3] Prabhawani, S. W. (2016). Pelibatan Orang Tua Dalam Program Sekolah Di Tk Khalifah Wirobrajan [Parental Involvement in School Programs at Tk Khalifah Wirobrajan]. PAUD Teacher Education S-1.

[4] Lestari, S. (2012). Psikologi keluarga: penanaman nilai dan penanganan konflik dalam keluarga (2nd ed.). Kencana.

[5] Rakhmawati, I. (2015). Peran Keluarga dalam Pengasuhan Anak [The Role of the Family in Parenting]. Jurnal Bimbingan Konseling Islam, 6(1). https://doi.org/10.21043/kr.v6i1.1037

[6] Zahrok, S., \& Suarmini, N. W. (2018). Peran Perempuan Dalam Keluarga [The Role of Women in the Family]. IPTEK Journal of Proceedings Series. https://doi.org/10.12962/j23546026.y2018i5.4422

[7] Alfiana, E. (2013). Pola Asuh Orang Tua Terhadap Anak Dalam Keluarga Pada Bidang Pendidikan Di Dusun Pandanan Desa Pandanan Kecamatan Wonosari Kabupaten Klaten [Parenting Patterns for Children in the Family in the Education Sector in Pandanan Hamlet, Pandanan Village, Wonosari District, Klaten Regency]. Universitas Negeri Yogyakarta. https://doi.org/10.1016/j.bbapap.2013.06.007 
[8] Puspitawati, H. (2018). Ekologi Keluarga: Konsep dan Lingkungan [Family Ecology: Concepts and Environment] (1st ed.). IPB Press.

[9] Hyoscyamina, D. E. (2011). Peran Keluarga Dalam Membangun Karakter Anak [The Role of the Family in Building Children's Character]. Jurnal Psikologi, 10(2), 144-152. https://doi.org/https://doi.org/10.14710/jpu.10.2.144-152

[10] Pramudyani, A. V. R. (2014). Peran orang tua sebagai guru pertama bagi anak usia dini [The role of parents as the first teacher for early childhood]. Jurnal Anak Usia Dini Edu [Journal of Early Childhood Edu], 1(2), 160-173. https://doi.org/https://doi.org/10.21831/jppm.v1i2.2686

[11] Arsendy, S., Sukoco, G. A., \& Purba, R. E. (2020). Riset dampak COVID-19: potret gap akses online 'Belajar dari Rumah' dari 4 provinsi [Research on the impact of COVID-19: portrait of the online access gap 'Learning from Home' from 4 provinces]. Theconversation.Com. https://theconversation.com/riset-dampak-covid-19-potret-gapakses-online-belajar- dari-rumah-dari-4-provinsi-136534

[12] Gloria. (2020). Sehat Mental Selama di Rumah dengan Aktivitas Positif Bersama Keluarga [Mental Health While at Home with Positive Activities with Family.]. Ugm.Ac.Id. https://ugm.ac.id/id/newsPdf/19175-sehat-mental-selama-di-rumahdengan-aktivitas-positif-bersama-keluarga

[13] Graha, C. (2007). Keberhasilan Anak di Tangan Orang Tua: Panduan Bagi Orang Tua Untuk Memahami Perannya dalam Membantu Keberhasilan [Children's Success in Parents' Hands: A Guide for Parents to Understand Their Role in Helping Success]. PT Elex Media.

[14] Ihsani, I., \& Santoso, M. B. (2020). Edukasi Sanitasi Lingkungan Dengan Menerapkan Perilaku Hidup Bersih Dan Sehat (Phbs) Pada Kelompok Usia Prasekolah di Taman Asuh Anak Muslim Ar-Ridho Tasikmalaya [Environmental Sanitation Education by Implementing Clean and Healthy Life Behavior (Phbs) In the Preschool Age Group at The Ar-Ridho Muslim Children's Fostering Center Tasikmalaya.]. Prosiding Penelitian $\begin{array}{llll}\text { Dan } & \text { Pengabdian } & \text { Kepada } & \text { Masyarakat, }\end{array}$ https://doi.org/10.24198/jppm.v6i3.22987

[15] Sanders, M. R. (2008). Triple P-Positive Parenting Program as a Public Health Approach to Strengthening Parenting. In Journal of Family Psychology. https://doi.org/10.1037/0893-3200.22.3.506

[16] Mattewakkang, A. J. (2020). Arah Pendidikan Di Masa Pandemi Covid-19 (Refleksi Hari Pendidikan Nasional) [Direction of Education During the Covid-19 Pandemic (Reflection on National Education Day)]. Takalarterkini.Com. http://takalarterkini.com/arah- pendidikan-di-masa-pandemi-covid-19-refleksi-haripendidikan-nasional/

[17] Ansori. (2020). Peran Kepala Sekolah di Saat Pandemi Covid-19 [The Role of School Principals During the Covid-19 Pandemic]. https://www.pintar.tanotofoundation.org/peran-kepala-sekolah-di-saat-pandemi- covid19/

[18] Harmaini. (2013). Keberadaan Orang Tua Bersama Anak [The Presence of Parents with Children]. Jurnal Psikologi UIN Sultan Syarif Kasim Riau., 1(1).

[19] Murtiningsih, D. (2013). Peran Orangtua Dalam Kegiatan Bermain Anak Usia Dini (46 Tahun) Di Rumah. Jurnal Pendidikan Luar Sekolah, 9(2), 1-21.

[20] Ministry of Education and Culture of the Republic of Indonesia. (2017). Waktu Berkualitas Bersama Anak [Quality Time with Kids]. Kemdikbud.Go.Id. 
https://sahabatkeluarga.kemdikbud.go.id/laman/uploads/Dokumen/4483_2017-

$02-$ 13/Waktu Berkualitas Bersama Anak.pdf

[21] Nurkholis. (2020). Dampak Pandemi Novel-Corona Virus Disiase (Covid-19). 6(1), 39-49.

[22] Harahap, F. I. N. (2018). Pengaruh Hasil Program Parenting Dan Pola Asuh Orang Tua Terhadap Peningkatan Motivasi Belajar Anak Usia Dini [The Effect of Parenting Program Results and Parenting Patterns on Increasing Early Childhood Learning Motivation]. Al-Muaddib: Jurnal Ilmu-Ilmu Sosial \& Keislaman, 3(1), 1-15. https://doi.org/10.31604/muaddib.v1i1.367 